\title{
Perceptions of Marginality: The Role of Administration and Other Stakeholders in Issues of Future Development of Czech Military Training Areas
}

\author{
TOMÁŠ SEIDL ${ }^{1}$, PAVEL CHROMÝ ${ }^{1}$, PAVLÍNA HABARTOVÁ \\ ${ }^{1}$ Charles University in Prague, Faculty of Science, \\ Department of Social Geography and Regional Development \\ ${ }^{2}$ Charles University in Prague, Faculty of Science, \\ Department of Demography and Geodemography
}

\begin{abstract}
Serious problems are becoming evident after 20 years of liberalization concerning the development of Czech military training areas (MTAs) and, in particular in their neighbouring zones. An important task is to devise procedures that emphasize essential conditions for the successful spatial and social integration of these marginal areas in the Czech regional system. The contemporary research presented is based on primary research of an area of special interest in the context of a situation analysis and specification of the role of local inhabitants of the military training area regarding issues of its functional use. The presented article analyzes the regional development intentions of the different hierarchical levels of board/administration (municipal, micro-regional, regional and departmental/governmental), concerning the role of an MTA in the regional system - in the case of MTA Boletice, this study's area of interest. The qualitative research presented is based on the analysis, interpretation and evaluation of primary data, procured through structured interviews and questionnaires carried out with representatives of local administration at various hierarchical levels. The attitudes of the primary stakeholders interested in the decommitment/conversion of MTAs are mainly concerned with investment benefits and project development locations rather than environmental protection legislation.
\end{abstract}

Key words: MTA, marginality, decommitment, regional development, Czechia

\section{Introduction, research context}

Although contemporary Czech geographical research has focused on the outer (borderlands) and inner peripheries in terms of spatial polarisation (Havlíček, Chromý, Jančák, Marada 2008; Jančák, Havlíček, Chromý, Marada 2008), only a few findings document the status of specific regions such as military training areas (MTAs). Interest in these topics has arisen primarily implicitly and the analyses are prepared in a different context. Research examining military training areas in Czechia consists solely of issues surrounding the conversion processes of the former military areas of Ralsko (located in Northern Bohemia) and Mladá (located in Central Bohemia north-eastward of Prague - see Fig. 2). MTAs, in particular, could be presumed to be very peripheral, practically marginal, zones (Chromý, Jančák 2005). The causes behind this lack of interest include, first and foremost, the 
external social/political environment and, second, a lack of information and data. The absence of an actual problem influenced the basis of such research. More serious problems appeared with the liberalization of relations. In connection with the increasing pressure placed on land-use, MTAs present a unique laboratory for studying ecology as well as social geography. They offer solutions to general issues surrounding the development of geographical systems - the monitoring and interpretation of spatial polarisation mechanisms. From the standpoint of regional development, they enable concrete, alternative or complementary development concepts of specific areas and their neighbouring zones to be determined (Seidl, Chromý 2010a).

The aim of this paper is to contribute to the discussion of spatial polarisation at the general level, the existence of marginal areas (the case of military training areas) and, finally, with the example of Boletice, to document the processes of the area's integration into the regional system. Another important purpose is to devise procedures and stress essential conditions for successful spatial and social integration. Areas with military training polygons routinely lacked any natural, social, cultural, historical or economic relationship with their surroundings. On the other hand, they present an opportunity for the restoration of so-called new islands of wilderness within the cultural landscape (Seidl 2008). As soon as the social climate allowed (after the Velvet Revolution in 1989), MTAs began to arouse public notice and to epitomize the free capacity for the development of society. Consequently, these spaces are sensitive to external intervention. Their continued evolution should be properly considered. It is important to contemplate all the positives and negatives of any proposed change in their functional use. An additional objective of this paper is to stress process failures and analyze their causes. This should serve to shed light on the process of backward integration into the regional system, expressing it in more precise terms.

We selected the southern Bohemian Boletice military training area and its surroundings as a research model, because of its dynamic evolution (Fig. 1). Neighbouring municipalities shall be the first territorial units influenced by any potential change in the functional use of MTAs (regardless of the chosen strategy of decommitment) (Seidl 2008). It is important to analyze the potential for participation in the process of development along the border zones of the MTA. As used here, decommitment represents the process of restructuring a territory under civic administration (Gazenbeek 2005). The contemporary research presented is based on primary research of the special-interest territory, in the context of situation analysis and the role of local inhabitants of the military training area in issues concerning its functional use (details in Seidl 2005, 2007; Zýval et al. 2005). It also results from studies and projects focused on the existence of MTAs in Czechia (e.g. Geografie Sborník ČGS Vol. 98/2 and Vol.103/3). The goal is to analyze regional development intentions at various hierarchical levels of administration (municipal, micro-regional, regional and departmental/governmental) regarding the role of the MTA in the regional system. 


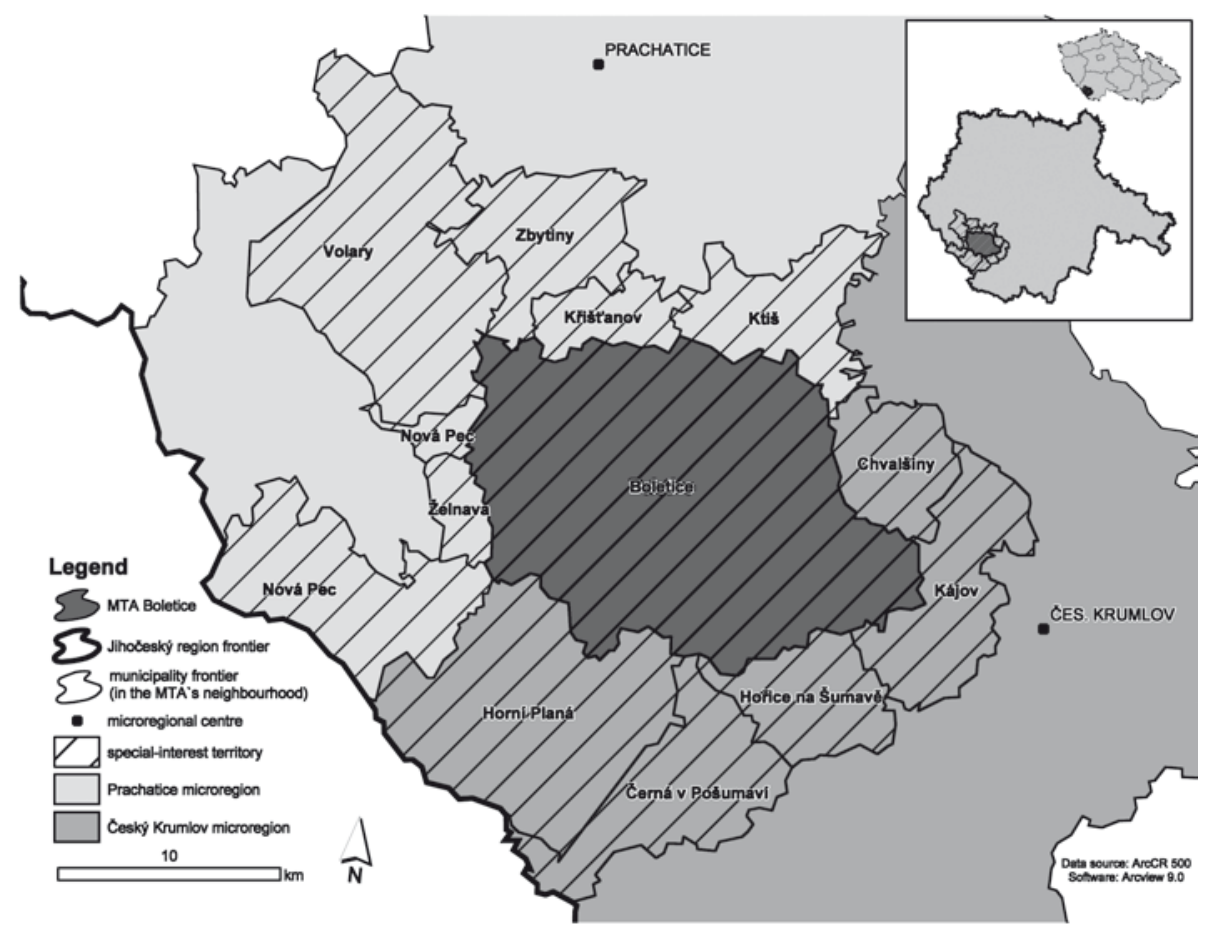

Fig. 1 Spatial and administrative demarcation of the special-interest territory, 2008

Source: Adjusted on the basis of Seidl (2008)

\section{Data and methodology}

In order to more systematically examine the process of internal spatial polarisation in the region, the original method of aggregate indexes construction, introduced by Kostić (2004) on the example of Czechia's inner peripheries, is used. We use statistical methods and 1991 and 2001 census data to show developmental trends. The qualitative research is based on the analysis, interpretation and evaluation of primary data procured through questionnaires and structured interviews with local representatives at different levels of administration. Above all, alternative possibilities for the regional development of the Boletice MTA were discussed. The research was carried out in 2007 and builds upon the first completed opinion poll of the Boletice MTA's inhabitants in its history (completed in 2004, see also Seidl 2005, 2007).

At a general level, the contemporary research dealt with practices applied in foreign military territories and utilised methods of comparison to identify primary features of the conversion/decommitment process which could be applied in the case of the Boletice MTA. The original study contains a unique balanced strategy, regarding how to make the area beneficial by implementing principles of sound tourism. This part as well as the attempt to assess the existing strategies of the Boletice MTA decommitment 
process using the SEA method (in accordance with Act No. 101/2001 Coll.) and making special consideration for the Natura 2000 network is not presented in this paper (for details see also Seidl, Chromý 2010a, Seidl 2008).

\section{Spatial polarisation - marginal areas in Czechia}

Polarisation is natural - from a communal point-of-view it is even considered a beneficial process. The existence of areas that are poorly integrated into the regional system always accompanies spatial polarisation. Theoretical and methodological aspects of polarisation and the problems of peripheries are widely discussed (e.g. Hampl 1998, 2003; Havlíček, Chromý 2001). However, Czech geographical or economic studies often view peripheries and marginal areas as being synonymous at a specific level. Peripheries are perceived as being geometrically distant, whereas marginal areas are, in addition to geometric distance, separated from the regional system (Jančák, Havlíček, Chromý, Marada 2006). As previously mentioned, the problems of marginality are closely related to issues of regional development, development strategies, sustainability and exploitation. Geometrically distant and poorly integrated regions, exhibiting lower levels of social and human capital, are more vulnerable to the destructive elements of material and socio-cultural resource exploitation. The problems of marginal regions are more complicated and complex than the problems of periphery and they should be resolved by external intervention (Chromý, Jančák 2005). Marginal areas often lack sufficient political support for changing developmental trends (Seidl, Chromý 2010a). The process of integrating a marginal area into the local, regional system leads to decreasing negative impacts on the neighbouring area. This works in the opposite direction as well. The genesis of MTA issues and questions of segregation/integration could be characterized in the manner described above.

The socio-cultural, economic and political characteristics of military training areas give evidence that these territories are the only large areas in Czechia that can be defined as marginal (Seidl, Chromý 2010a). Although geographers are interested in research on the formation of connections in space, solutions concerning the integration of former or existing MTAs are only partially discussed. Such an attitude is evident throughout Central and Eastern Europe - primarily due to its perceived irrelevancy and historical causes (the Cold War, Iron Curtain zones and totalitarian regimes). Crucial aspects in the allocation of nearly all Czech MTAs included, first and foremost, geographical conditions and very low population density, resulting from political and socio-demographical changes during and after WW II. The presence of the Iron Curtain belt played its own special role. Four of the nine former Czech MTAs were located near the western Czechoslovak/Czech borders (Fig. 2). 


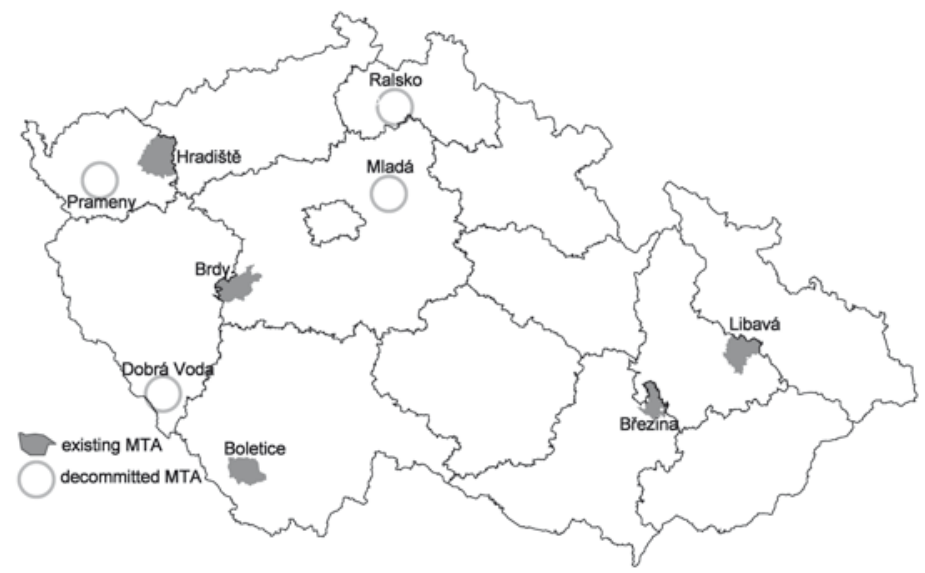

Fig. 2 The location of Czech military training areas, 2009

Source: Authors

In some places, the Iron Curtain belt ${ }^{1}$ reached as much as fifteen kilometres in width and it could be considered an example of a marginal area similar to the MTAs (an extreme type of periphery in Czech geographical conditions) (see also Seidl, Chromý 2010b). At the beginning of the 1990s, the combined area of all MTAs in Czechoslovakia reached more than $2600 \mathrm{~km}^{2}$ (more than $2 \%$ of the total area of the state). A quarter of the area fulfilled primary military-strategic functions (Komár 1993). In connection with admittance into NATO and the process of the professionalization of the Czech army, not only is the number of small-area training polygons being reduced, the surface area of large training polygons such as MTAs is also decreasing. According to the new Act No. 222/1999 Coll. and the latest analysis from the Ministry of Defence (2007) all existing MTAs are necessary in securing adequate conditions for military training. This declaration was used as a primary prediction within our research. The declaration also responds to the increasing pressures of decommitment. In general, the total area of military training areas decreased throughout Europe after the end of the Cold War. However, the unique nature of the large-area military polygons in Czechia, Slovakia and Poland allows for their continued existence. The economic profits from leasing are of great interest for the defence sectors of these three countries.

Western European MTAs were established in economically insignificant regions, which epitomized peripheral locations at the time of their creation. In both Eastern and Western Europe, however, the ultimate status after decades of military use is the same: unique natural treasures and an abundance of natural and semi-natural habitats are concentrated in MTAs (Seidl, Chromý 2010a). In fact, the region surrounding Český Krumlov (in Boletice MTA's hinterland), which has been regarded as a strong periphery (Hampl, Gardavský, Kühnl 1987), still represents an economically weak region. On the basis of outcomes from the quantitative research (Seidl 2008), analysing the process of

1 A two-kilometre wide border zone was a special, entirely blocked-off sector, with no entrance or free movement permitted, very similar to the regime in MTAs. 
inner spatial polarisation, we can affirm that the municipalities surrounding Boletice MTA exhibit deepening periphery effects - especially between the years of 1991 and 2001.

After 1991, strengthening impulses for decommitment can be recognized. During the last six years, however, aspirations to abolish the entire polygons have surfaced. Initiative originates from the local or regional administration as well as from the private sector. The strength of such initiatives clearly depends on the political climate. In our opinion, it is important to stress the role of strategic planning and the avoidance of non-conceptual solutions. The first reaction appeared with the publication of a study entitled "Boletice - A Study of Polyfunctional Use" (Zýval et al. 2005), which uses the outcomes of our original research (e.g. Seidl 2005). Up until 2006, the MTA boundaries exhibited an entirely locked political character, resulting in a territorial effect that divided two functionally divergent spaces. Tendencies concerning the MTA border penetration have been amplified by the Ministry of Defence in coordination with regional administration and the local military administration of Boletice MTA. For example, due to the most recent Ministry of Defence Decree No. 2025-25/2007, the border zones can be entered under certain conditions. According to foreign experience, these tendencies should intensify in the Czech environment. Contact border effects are more significant now. Considering its unique military conditions, the integration process will be more spatial than socioeconomic in nature for the MTA. In spite of this, the process could influence the MTA's surroundings socio-economically. Accessing specific MTA border zones will develop as a concentration border effect, which centralizes the processes into selected directions (similarly Dokoupil 2004). The problem is whether it will be possible to anticipate any changes in the inner spatial polarisation of the entire region. A very important question is whether any change will have a negative impact on the fundamentals of environmental protection, outlined in the Natura 2000 network and sites. Negative impacts could be related to local carrying capacity and negative manifestations of tourism.

\section{Empirical analysis and interpretation of the survey}

In order to explain the temporal aspects of MTA Boletice marginality, we present the results of the applied research and the primary data collected. The data were acquired through questionnaires and structured interviews with the representatives of local administration in the special-interest territory and at hierarchically higher levels of administration (Tab. 1). The focus group consists of mayors of the MTA's neighbouring municipalities, the directors of various specialized departments of microregional and regional administration (environmental, regional development, tourism) as well as experts from the Šumava National Park and Protected Landscape Area (Šumava PLA) and experts at the ministerial level (defence and environment). Interpretation of the structured interviews affords an opportunity to categorize the special-interest territory (especially the municipalities) into groups supporting different levels of conversion/decommitment. 
Table 1 Levels of application of the questionnaire and structured interviews in public administration, 2007

\begin{tabular}{|l|c|c|l|l|}
\hline $\begin{array}{l}\text { Levels of } \\
\text { application }\end{array}$ & $\begin{array}{c}\text { Number } \\
\text { of subjects } \\
\text { at various } \\
\text { levels }\end{array}$ & $\begin{array}{c}\text { Number of } \\
\text { stakeholder } \\
\text { divisions at } \\
\text { administrative } \\
\text { levels }\end{array}$ & \multicolumn{1}{|c|}{ Specification } & $\begin{array}{c}\text { Relevant sphere of } \\
\text { action }\end{array}$ \\
\hline Municipality & 11 & 11 & Municipal office & $\begin{array}{l}\text { physical planning, } \\
\text { decrees, actual living }\end{array}$ \\
\hline MEC & 2 & 4 & $\begin{array}{l}\text { Regional development }- \\
\text { Environmental } \\
\text { protection }- \\
\text { departments }\end{array}$ & $\begin{array}{l}\text { inoperative } \\
\text { administration }\end{array}$ \\
\hline Region & 1 & 3 & $\begin{array}{l}\text { Regional development }- \\
\text { Environmental } \\
\text { protection }- \text { Tourism } \\
\text { and marketing }-\end{array}$ & $\begin{array}{l}\text { physical planning } \\
\text { (regional level), } \\
\text { strategic planning } \\
\text { (regional level), } \\
\text { politics }\end{array}$ \\
\hline Ministry & 2 & 2 & Defence; Environment & $\begin{array}{l}\text { politics, acts, } \\
\text { regulations, directives }\end{array}$ \\
\hline & 1 & 1 & $\begin{array}{l}\text { PLA Šmanas } \\
\text { physical planning, } \\
\text { regional management } \\
\text { and marketing, } \\
\text { education and } \\
\text { edification }\end{array}$ \\
\hline
\end{tabular}

Source: Authors

The first group of respondents extols the importance of a crucial project. A project realized in the field of hard tourism could influence the spatial polarisation, through its economic impacts. In contrast, the second group of respondents supports alternative forms of Boletice MTA exploitation. These respondents also note the impossibility of changing the area's position in the regional system (Chart 6), with the possible exception of sequential development cooperation with military authorities. Support rates depend on the geographical location of a given municipality or microregion. Generally, municipalities located south of Boletice MTA, along with the regional administration, support decommitment more intensively and recognize opportunities to use the area's rugged topography for the purposes of hard winter tourism. Our survey confirms the existence of a communication barrier within the administrative hierarchy of the entire region as well as between NGOs and the private sector. On one side, there are involved persons and economic subjects promoting projects, which cannot be realized because of legislation protecting the environment. While on the other side, groups of civil corporations and environmentalists support environmental protection, but are not perceived as providing solutions for existing regional problems of unemployment and the economic concerns. Three quarters of the respondents view at least partial decommitment 
as a strong impulse in the municipal development process. The group of respondents, who underestimate the role of national park and environmental protection and branding as well as their role in regional marketing, is in favour of significant changes in land use in the MTA. Nature protection (the presence of the Natura 2000 network) in addition to military use is, in the case of Boletice MTA, a fundamental condition in strategy preparation. As such it is embedded in the national legislation. Legislative protection of the environment (high natural potential) represents an impulse in the development process (the marginal region integration process) for nearly half of all respondents. One third regards such protection as an essential role in the process (Chart 3). On the other hand, a similarly large portion of respondents identify a barrier to the regional development process in connection with implementation of the Natura 2000 network and the intensifying tendency of environmental protection issues.

Publicly known projects promoting the interests of hard tourism (such as a winter sports area) are designed to cover quite a large portion of the military area. This is the primary reason behind endeavours to decommit or change the demarcation of the Boletice MTA. Such voices are often more noticeable due to the financial support of the stakeholders involved. The research, however, gives evidence that support for decommitment is partial. The demarcation appears more clearly for the overall purpose and is supported by more than one third of respondents (Chart 2). All of the tendencies are dependent on political conditions. During a very short period before the last parliamentary elections in 2006, a joint declaration including a specific MTA demarcation change appeared (for more information see: Collective declaration of the Ministry of Defence, 2006). In spite of this, half of the respondents across all the hierarchical levels of administration still prefer keeping the MTA's current boundaries and will support any possible cooperation and synergy to conserve the natural value of the territory and to reduce the negative impacts of the area's marginal and peripheral position in the regional system. One potential solution is EU subsidies, especially those that are environmentally focused, such as LIFE budget.

Tendencies aimed at facilitating cooperation between the three main stakeholders in MTA use issues (the Ministries of Defence and the Environment, including NGOs, the public and private sector, represented by elected representatives of the administration) run up against an entrenched communication barrier and significant preconceptions (in the words of respondents). This is one of the most serious factors behind the attitude towards Boletice MTA's role in the regional system. For one half of the respondents the area represents a barrier to municipal development. Slightly more than one third of the sample have an opposite opinion and are able to accept current status (Chart 1).

The survey results presented supplement the outcomes of the inner polarisation analysis based on census data. The following Population and housing census 2011 in Czechia will provide new sort of data regarding population size in spatial projection due to EU regulations. The population size of the spatial units will be based on place of usual residence. In other words it means that the size and structure of population and private households may differ in comparison with the current conditions based on place of permanent residence (Habartová 2009). This innovation could influence the perceptions of peripheries and marginality therefor. Answers to the question regarding perception of the special-interest territory, especially its core - Boletice MTA - also 
show respondents' attitudes towards MTA Boletice's position in the regional system. Qualitative classifications are influenced by the attitudes of respondents, their feelings and experiences. Local inhabitants, naturally, reduce the extremity of the perception of marginality (Charts 4 and 5).
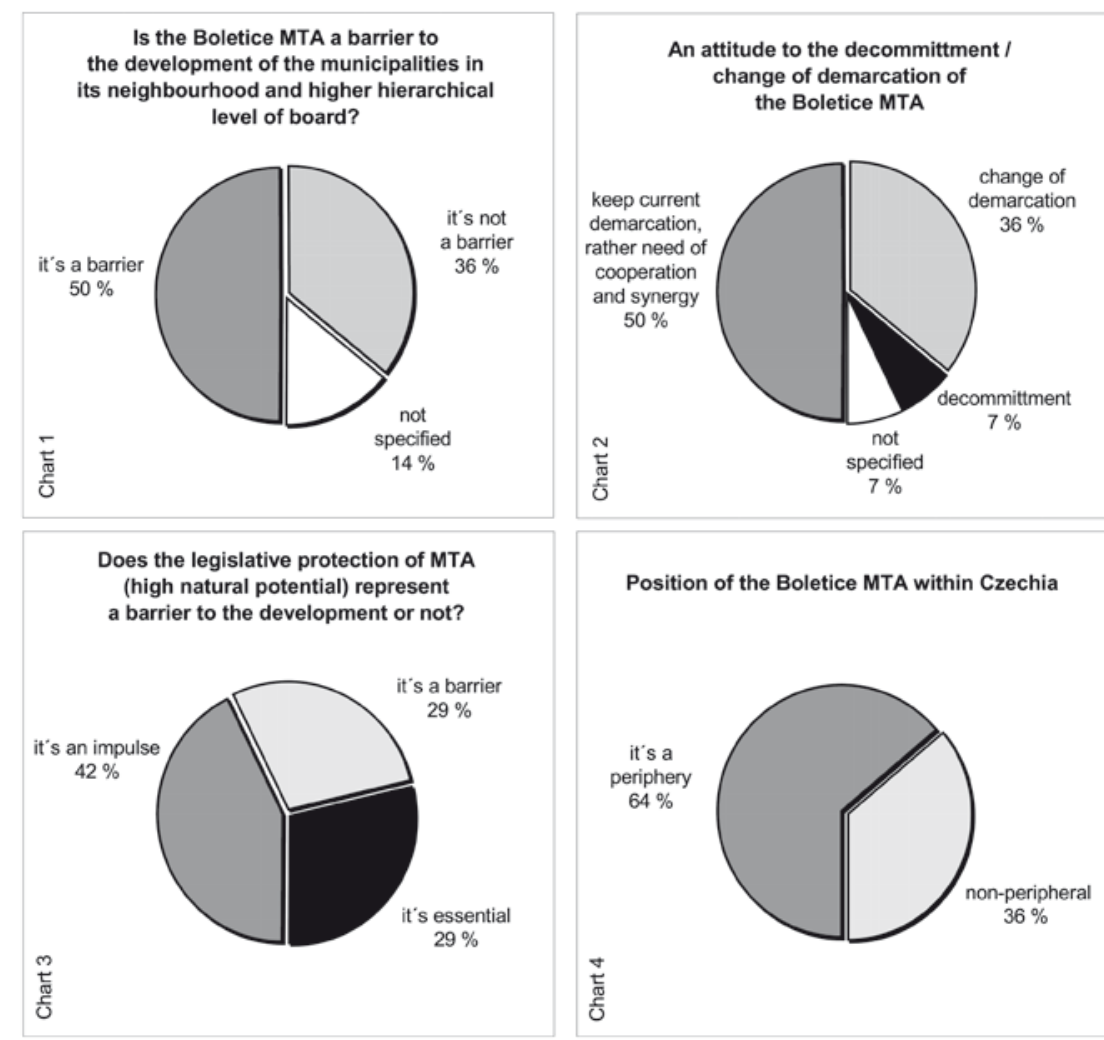

Position of the Boletice MTA within Czechia
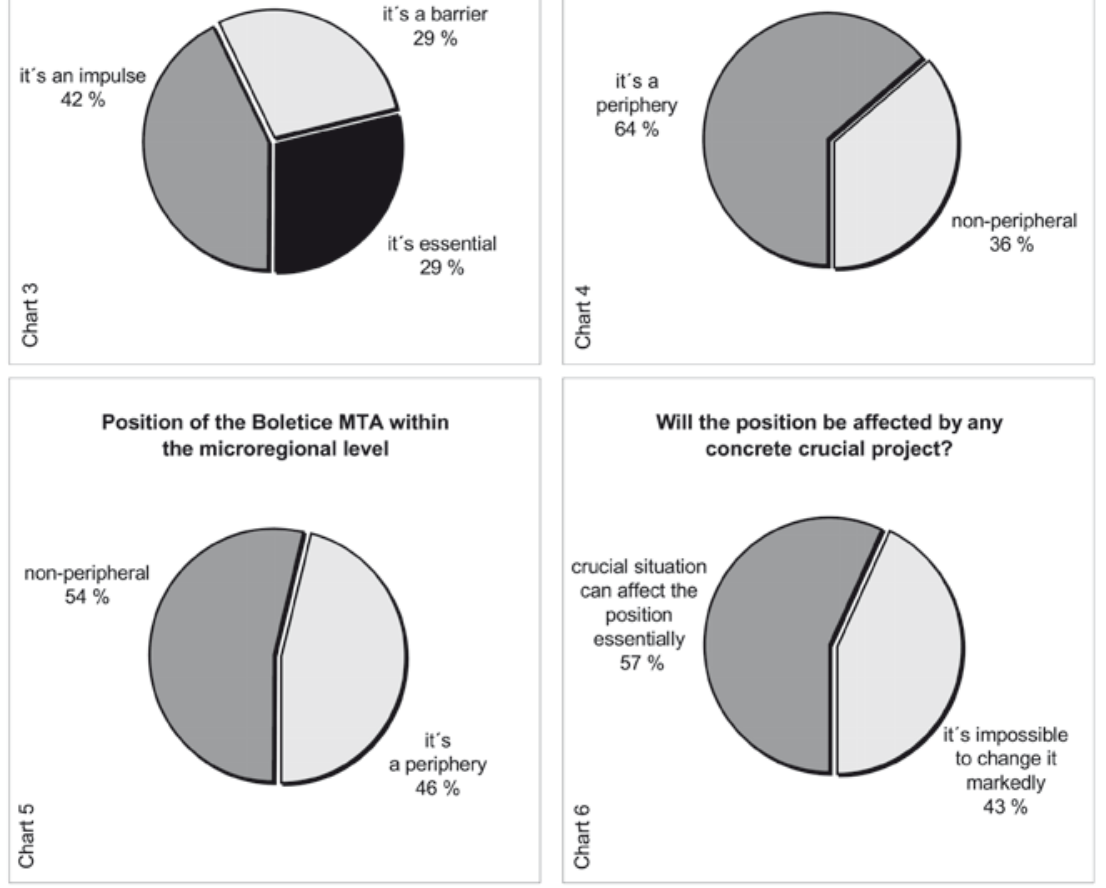

Chart 1-6 Selected attitudes of respondents, special-interest territory of Boletice, 2007

Source: Adjusted on the basis of Seidl (2008) 


\section{Conclusions}

Because of its high natural potential, Boletice MTA has been the subject of an ongoing discussion concerning how to turn the area into an advantage, especially for tourism needs. A change in military management allows for the penetration of the military area's borders and makes certain sites accessible to sound tourism. On the other hand, interest in the decommitment of some parts of the military area for hard tourism also exists. This interest is presented as a means of solving regional problems of unemployment and instability in the periphery. Such tendencies are in conflict with the fundamentals of environmental protection and Natura 2000 network implementation. EU member states are obliged to ensure and provide permanent legislative protection in defined Special Protection Areas (SPAs) and Sites of Community Importance (SCIs). There is nearly a complete lack of cohesion between environmental aspects and the currently presented projects (which are mainly supported by select local and regional administration along with private investors). Military use has been identified by eminent environmentalists as a positive way of preserving the unique natural value of MTAs.

The object of this paper was to outline the attitudes of central stakeholders interested in decommitment. Survey outcomes focused on their behaviour and expectations regarding the discussed themes of the integration process and strategy building. Due to its specific conditions, the MTA is almost entirely detached from its surroundings in terms of social, economic and political cooperation (removed from the regional system). It is important to note that this status is achieved artificially.

As well as we can define the degree of marginality of the problem area, by using inner spatial polarisation analysis, we can estimate the temporal duration of the marginality in question. There is a lack of best practice references or model cases of decommitment realized abroad (Seidl, Chromý 2010a, Seidl 2008). The decommitment process, as well as the cross-sectional cooperation of various sectors (military, environment, regional development), is more frequently applied in Western Europe. These aspects are very important in strategic planning. A solution should be sought in cooperation across administrative levels as well as in cooperation with local institutions, special interest groups and, in particular, with local inhabitants.

\section{Acknowledgement}

This paper is the result of research findings sponsored by a grant project GA UK No. 58610 "Spatial Development Problems of the Former and Existing Militarily Used Areas" and is being realised with the support of a financial grant project from the Czech Science Foundation (GAČR): No. 403/09/1491 "The Significance of Tourist Function of Settlements and Municipalities in the Process of Formation of Regional Identity and Identity of Regions in CR" and by The Joint Research Scheme MSM 0021620831 of the Czech Ministry of education. 


\section{References}

Collective declaration of Ministry of Defence, Ministry of the Environment, Local Development Ministry, South Bohemian Region in re of civil use of the Boletice MTA, Prague, 2006 [online]. 2007 [cit. 200710-20]. Accessible <http://www.kraj-jihocesky.cz/>.

Czechia. Act No. 222/1999 Coll. In Sbírka zákonů České republiky. 1999, částka 76. Accessible also WWW: $<$ http://www.portal.gov.cz>.

Czechia. Act No. 101/2001 Coll. In Sbírka zákonů České republiky. 2001, částka 41. Accessible also WWW: $<$ http://www.portal.gov.cz>.

DOKOUPIL, J. (2004): Hranice a hraniční efekt. In: Jeřábek, M., Dokoupil, J., Havlíček, T. a kol.: České pohraničí - bariéra nebo prostor zprostředkování? Academia, Praha, pp. 47-58.

GAZENBEEK, A. (2005): LIFE, Natura 2000 and the military. European Commision, Environment DG, Luxembourg, $79 \mathrm{p}$.

Geografie - Sborník ČGS, 1993, Vol. 98, No. 2.

Geografie - Sborník ČGS, 1998, Vol. 103, No. 3.

HABARTOVÁ, P. (2009): Domácnosti v SLDB 2011. Demografie, 51, 3, pp. 202-204.

HAMPL, M. (1998): Realita, společnost a geografická organizace: hledání integrálního řádu. Př́rodovědecká fakulta, Univerzita Karlova, Praha, 110 p.

HAMPL, M. (2003): Diferenciace a zvraty regionálního vývoje Karlovarska: unikátní případ nebo obecný vzor? Geografie, 108, 3, pp. 173-190.

HAMPL, M., GARDAVSKÝ, V., KÜHNL, L. (1987): Regionální struktura a vývoj systému osídlení ČSR. Univerzita Karlova, Praha, $255 \mathrm{p}$.

HAVLÍČEK, T., CHROMÝ, P. (2001): Př́íspěvek k teorii polarizovaného vývoje území se zaměřením na periferní oblasti. Geografie, 106, 1, pp. 1-11.

HAVLÍČEK, T., CHROMÝ, P., JANČÁK, V., MARADA, M. (2008): Innere und ausere Peripherie am Beispiel Tschechiens. Mitteilungen der Österreichischen Geographischen Gesellschaft, 150, pp. 299-316.

CHROMÝ, P., JANČÁK, V. (2005): Periferní oblasti Česka jako jeden z pólů polarizovaného prostoru. Životné prostredie, 34, 2, pp. 106-108.

JANČÁK, V., HAVLÍČEK, T., CHROMÝ, P., MARADA, M. (2006): Research on peripheral regions in Czechia: Theoretical and methodological remarks and basic results. Acta Geographica Universitatis Comenianae, 48, pp. 89-99.

JANČÁK, V., HAVLÍČEK, T., CHROMÝ, P., MARADA, M. (2008): Regional Differentiation of Selected Conditions for the Development of Human and Social Capital in Czechia. Geografie, 113, 3, pp. 269-284.

KOMÁR, A. (1993): Vojenský újezd Hradiště. Geografie - Sborník ČGS, 98, 2, pp. 75-86.

KOSTIČ, M. (2004): Vnitřní periferie v Česku: př́klad středočesko-jihočeského pomezí. Magisterská práce. UK v Praze, PřF, katedra sociální geografie a regionálního rozvoje, Praha, 112 p.

Ministerstvo obrany České republiky (2007): Analýza existence vojenských újezdů z hlediska porovnání potřeb armády a stanovených ekonomických kritérií, aktualizace materiálu k 1. březnu 2007. MO ČR, Praha.

SEIDL, T. (2005): Potenciál rozvoje př́hraničního regionu Boletice. Bakalářská práce. Západočeská univerzita, Pedagogická fakulta, katedra geografie, Plzeň, $77 \mathrm{p}$.

SEIDL, T. (2007): Geografický potenciál regionu Boletice. In: Petříček, V., Kuchařová, P.: Ochrana přírody a krajiny ve vojenských újezdech. AOPK ČR, Praha, pp. 85-92.

SEIDL, T. (2008): Proces integrace marginálního území do regionálního systému - př́íklad Vojenského újezdu Boletice. Diplomová práce. UK v Praze, PřF, katedra sociální geografie a regionálního rozvoje, Praha, $119 \mathrm{p}$.

SEIDL, T., CHROMÝ, P. (2009): Turismus v alternativních chráněných územích - koncentrovaná exploatace nebo šetrné formy? Dobrá praxe v udržitelnosti cestovního ruchu. Univerzita Hradec Králové, Hradec Králové, pp. 50-57.

SEIDL, T., CHROMÝ, P. (2010a): Problémy integrace marginálního území do regionálního systému: př́íklad Vojenského újezdu Boletice. Geografie, 110, 1, pp. 44-63.

SEIDL, T., CHROMÝ, P. (2010b): Environmental Conservation in Military Training Areas - Source of Spatial Conflicts? EUROPA XXI (review).

ZÝVAL et al. (2005): VÚ Boletice - studie polyfunkčního využití. Geovision, Plzeň, 79 p. 


\section{Résumé \\ Percepce marginality: role veřejné správy a aktérů regionálního rozvoje v otázkách budoucího vývoje českých vojenských újezdů}

V průběhu posledních dvou dekád liberalizace společnosti, uvolnění poměrů, se stále zřetelněji prosazují zájmy a s nimi též problémy týkající se využívání českých vojenských újezdů s předpokládanými dopady na vývoj/rozvoj sousedících správních celkủ. V tomto ohledu je nezbytné navrhnout postupy, které vyzdvihnou základní předpoklady úspěšné prostorové a sociální integrace zmíněných marginalizovaných oblastí Česka (vojenských újezdů) do regionálního systému.

Příspěvek se zabývá rolí aktérů regionálního rozvoje a především veřejné správy v otázkách budoucího vývoje marginalizovaných území. Je zde akcentována percepce periferních území (dle konceptu jádro-periferie) $\mathrm{s}$ důrazem na oblasti vyčleněné $\mathrm{z}$ ekonomických, sociálních i politických vazeb na okolní prostředí (marginalizované zóny). Současný výzkum je založen na původním výzkumu v kontextu konstrukce situační analýzy zájmového území VÚ Boletice zahrnující analýzu role místních obyvatel vojenského újezdu v oblasti ovlivnění budoucího funkčního využití území. Dále se zde analyzují záměry a postoje rozlišných úrovní veřejné správy (úroveň obecní, mikroregionální, regionální, sektorová ministerská, zájmová a specifická) s ohledem na možnosti využití/konverze vojenských majetků. Kvalitativní povaha výzkumu je založena na analýze, interpretacích a hodnocení primárních dat poskytnutých prostřednictvím strukturovaných interview a anketního šetření.

Z výsledků výzkumu jednoznačně vyplývají závěry charakterizující jednak protichůdné postoje aktérů regionálního rozvoje ve vztahu k marginalizovaným vojenským zónám ovlivněné možným investičním a ekonomickým profitem z navržených záměrů, projektů, jednak absence diskuze o koordinovaném př́stupu k řešení územních problémů mezi jednotlivými úrovněmi veřejné správy (od lokální po ústřední), resorty státní správy a soukromými subjekty. Legislativa na ochranu environmentálních hodnot území (př́rody a krajiny) je akcentována až $\mathrm{v}$ př́padech, kdy daný ekonomický záměr nenese př́mý ekonomický zisk pro konkrétní správní území. Mj. proto se jako nezastupitelná jeví role správy zvlaššě chráněných území v oblasti edukace, osvěty, managementu a marketingu environmentálně vysoce cenných marginalizovaných oblastí v rámci českých vojenských újezdů.

Tomáš Seidl, Pavel Chromý,

Charles University in Prague, Faculty of Science Department of Social Geography and Regional Development

Albertov 6

12843 Prague 2

Czech Republic

e-mail: tomas.seidl@centrum.cz,chromy@natur.cuni.cz

Pavlina Habartová

Charles University in Prague, Faculty of Science Department of Demography and Geodemography

Albertov 6

12843 Prague 2

Czech Republic

e-mail: pavlina.habartova@seznam.cz 